\title{
Bioeconomic simulation analysis of hake and red mullet fishery in the Gulf of Saronikos (Greece)
}

\author{
GORKA MERINO ${ }^{1}$, CONSTANTINA KARLOU-RIGA ${ }^{2}$, IOANNA ANASTOPOULOU ${ }^{2}$, \\ FRANCESC MAYNOU ${ }^{1}$ and JORDI LLEONART ${ }^{3}$ \\ ${ }^{1}$ Institut de Ciències del Mar - CSIC, Psg. Marítim de la Barceloneta 37-49, 08003 Barcelona, Spain. \\ E-mail: gmerino@icm.csic.es \\ ${ }^{2}$ Ministry of Rural Development and Food, Fisheries Laboratory, Karaoli and Demetriou 15, 18531 Piraeus, Greece. \\ ${ }^{3}$ FAO, Via delle Terme di Caracalla, 00153 Rome, Italy.
}

SUMMARY: Hake (Merluccius merluccius) and red mullet (Mullus barbatus) are two of the most important species in Greek fisheries due to their high commercial interest. Both have been reported to be overexploited and in need of management to preserve the continuity of their exploitation. Hake is exploited by trawlers and red mullet by both trawlers and beach seiners in Saronikos Gulf (Greece). The MEFISTO bioeconomic simulation model is applied in order to test the interaction between trawlers and beach seiners through the age-specific fishing mortality applied by each fleet to the red mullet stock. The effects of the withdrawal of some beach seiners in 2002 and the increase in trawl mesh size that has already been implemented (from $28 \mathrm{~mm}$ to $40 \mathrm{~mm}$ stretched mesh) are tested jointly with alternative management scenarios such as the complete withdrawal of beach seiners and effort reduction in trawler activity. The analysis of the simulation results is based on the evolution of biological and economic indicators through 15-year stochastic projections. It is shown that limiting fishing effort and improving selectivity patterns of the trawl fleet would be beneficial for the recovery of the populations and for the profitability of the fishery. In addition to the increase in trawl mesh size, a further fishing effort reduction of $12 \%$ is recommended for the trawling fleet. Conversely, limiting or completely removing the beach seiner fleet would protect red mullet juveniles but would not significantly increase the profitability of the trawling fleet, and it would cause unemployment.

Keywords: Saronikos Gulf, trawl fisheries, beach seiner, European hake, red mullet, fisheries management, bioeconomic model.

RESUMEN: La merluza (Merluccius merluccius) y el salmonete (Mullus barbatus), debido a su gran interés comercial, son las dos especies más importantes de las pesquerías griegas. Ambas especies se encuentran en situación de sobreexplotación y necesitadas de una gestión adecuada que proteja la continuidad de su explotación. En el Golfo de Saronikos (Grecia), la merluza es explotada por la flota de arrastre mientras que el salmonete lo pescan las flotas de arrastre y la de cerco de playa. Se utiliza el modelo de simulación MEFISTO para el análisis de la interacción de ambas flotas a través de las mortalidades pesqueras aplicadas sobre las clases de edad del salmonete. En el presente trabajo se evalúan los efectos de la retirada de algunos cerqueros que tuvo lugar en 2002 y del incremento del ancho de malla (desde $28 \mathrm{~mm}$ a $40 \mathrm{~mm}$ ) que tuvo lugar en 2000, así como algunos escenarios de gestión alternativos como la completa retirada de la flota de cerco o la reducción del esfuerzo pesquero de la flota de arrastre. El análisis de las simulaciones estocásticas se presenta a través de la evolución de los indicadores bioeconómicos durante 15 años. Se muestra que la limitación del esfuerzo pesquero y la mejora en los parámetros de selectividad de la flota de arrastre serían beneficiosos tanto desde un punto de vista económico como conservacionista. Por otro lado, se recomienda una reducción de esfuerzo del $12 \%$. Por el contrario, la limitación o retirada de la flota de cerco de playa causaría un problema de desempleo y no permitiría aumentar los beneficios de la flota de arrastre, sin llegar a ser beneficioso para las poblaciones explotadas.

Palabras clave: Golfo de Saronikos, pesquería de arrastre, cerco de playa, merluza europea, salmonete, gestión de pesquerías, modelo bioeconómico. 


\section{INTRODUCTION}

Techniques based on stochastic simulation models have been developed in recent years to evaluate alternative management strategies of fisheries (Punt, 1992, 1993; Sparre and Willman, 1993; Horwood, 1994; Ulrich et al., 2002; Griffin, 2003; Lleonart et al., 2003). These techniques allow the projection of biological and economic indicators to be examined over time, under different conditions or scenarios derived from the alternative management strategies being tested.

A bioeconomic fisheries model (MEFISTO) taking into account the specificities of Mediterranean fisheries has been developed by Lleonart and collaborators (Lleonart et al., 2003; Maynou et al., 2006). Mediterranean fisheries are typically multispecies and have a cost structure based on the share system, in which the economic agent is the individual vessel (Lleonart and Maynou, 2003). Management of Mediterranean fisheries is not adaptive, as in other European fisheries, i.e. assessments of stocks in one year are not used to implement new management measures in the following year. MEFISTO allows a wide range of management measures to be tested, including those typically employed by Mediterranean fisheries managers. For this reason, it was chosen as the tool to evaluate different management strategies for the trawl and beach seiner fleets of Saronikos Gulf fishery.

Saronikos Gulf has a large variety of sea bottom types and a variety of fisheries take place in the area (Karlou-Riga and Vrantzas, 2001). Moreover, protection from the winds and the proximity of the most important Greek fish market (Piraeus) makes fishing in this zone a very attractive activity. The total landings recorded for the year 2001 in the area were $8,347 \mathrm{t}$ (NSSG, 2000), representing $10 \%$ of the total catch in Greek waters. The value of landings for 2001 was $€ 250,280$ (NSSG, 2000). Hake landings constitute $3.8 \%$ of the total annual fish landings in the country and $3.1 \%$ of the total catch in Saronikos Gulf (NSSG, 2003), but the landings of hake by trawlers in Saronikos Gulf represent 52.4\% of the national hake landings. Red mullet landings constitute $2.1 \%$ of the total annual landings in the country and $1.8 \%$ of the total landings in Saronikos Gulf (NSSG, 2003). Red mullet is fished essentially by trawlers and beach seiners.

European hake, Merluccius merluccius, and red mullet, Mullus barbatus, are two of the most impor- tant resources for the bottom trawl fleets in Greece (eastern Mediterranean), in terms of both catch and economic value. Saronikos Gulf, located in central Greece, is a semi-enclosed area with a maximum depth of up to $400 \mathrm{~m}$. The fishing grounds for the trawling fleet are distributed in a depth range between 100 and $400 \mathrm{~m}$ although trawlers are scarcely operative at $400 \mathrm{~m}$ (western limit of the Gulf). The trawling fleet operating in Saronikos Gulf is composed by eighteen vessels that, in addition to hake and red mullet, have a very heterogeneous landings composition including species such as red pandora (Pagellus erythrinus), striped mullet (Mullus surmuletus), picarel (Spicara smaris), horse mackerel (Trachurus sp.), deep-sea shrimp (Parapenaeus longirostris), Norway lobster (Nephrops norvegicus), common octopus (Octopus vulgaris) and squid (Loligo vulgaris). Trawlers operate for 8 months a year, from October to the end of May (Karlou-Riga and Vrantzas, 2001).

Beach seiners operate in shallow waters up to 50 $m$ depth. The beach seiner fleet in Saronikos Gulf was composed of 35 vessels in 2000. The fleet targets red mullet, but its landings also include picarel, red pandora, striped mullet and squid. Beach seiners operate for 6 months a year, from October to March.

The stocks of the two species analysed here have been assessed (Karlou-Riga et al., 2000; KarlouRiga and Vrantzas, 2001; Karlou-Riga et al., 2005) in the framework of the Subcommittee on Stock Assessment (SCSA) of the General Fisheries Commission of the Mediterranean (GFCM).

Conflicts between inshore fleets (beach seiners, netters and longliners) and trawlers arise for different reasons. Netters and longliners perceive that beach seiners are harmful to sea-grass beds of Posidonia oceanica and to juveniles of red mullet. On the other hand, net and longline fleets complain that they lose their gears to trawlers when they operate in fishing grounds deeper than $100 \mathrm{~m}$. As a consequence, policy proposals aimed at reducing the conflict are being considered. We used the MEFISTO bioeconomic fisheries simulation model to evaluate different strategies that have been designed: i) a change in the trawlers' mesh size which took place in 2000 and the withdrawal of eleven beach seiners in 2002; ii) a reduction of the fishing period for trawlers; and iii) total withdrawal of the beach seine fleet. The results of the simulations are examined, considering the effect of the management strategies on the population of the two main stocks (hake and 
red mullet) and the effect on the profitability of the fishery.

\section{MATERIAL AND METHODS}

\section{The model}

The MEFISTO bioeconomic simulation model (Lleonart et al., 2003), tailored to Mediterranean fisheries specificities, includes the following features:

i. Management of Mediterranean fisheries is mainly based on input controls, i.e. effort control and technical measures (selectivity). The MEFISTO simulation model includes the possibility of testing the effects of removing vessels from the fishery or reducing their fishing time, as well as changing the selectivity patterns by age class.

ii. Catchability dynamics. In an input control regulation scheme, fishermen have the possibility of increasing fishing mortality through technical improvements, which result in increased catchability. The model can be used to simulate the effect of investments in technology that would increase the catchability of individual vessels in time.

The model comprises three submodels: The stock box, the market box and the fisherman (or decision) box.

\section{The stock box}

The stock box simulates the dynamics of the resource and uses the standard equations of population dynamics. The model accepts two categories of exploited populations: the target and the secondary species. The secondary species dynamics is directly related to the target species dynamics (see below). The target population is described through an agestructured model (Schnute, 1985). The number of individuals of age $a+1$ at time $t+1$ is:

$$
N_{a+1, t+1}=N_{a, t} \exp \left(-Z_{a, t}\right)
$$

where $N_{a, t}$ is the number of individuals of age $a$ at time $t$ and $Z_{a, t}$ is the total mortality when age is changed from $a$ to $a+1$.

The average number of individuals during the age-class interval $a$ is:

$$
\bar{N}_{a, t}=N_{a, t} \frac{1-\exp \left(-Z_{a, t}\right)}{Z_{a, t}}
$$

The total mortality is the combination of fishing mortality $F_{a, t}$ and natural mortality, $M_{a}$, assumed to be constant over time:

$$
Z_{a, t}=F_{a, t}+M_{a}
$$

The fishing mortality applied to a target species is the sum of the mortalities applied by the gears exploiting it. The fishing mortality for each gear is calculated with the gear selectivity (S) and catchability parameters (q), jointly with the fishing effort $(E)$ applied by each gear. Selectivity and catchability are related to age (a), time (t) and gear $(\mathrm{g})$. This equation makes it possible to test the effects in gear selectivity patterns.

$$
\begin{gathered}
F_{a, t}=\sum_{g}^{G} F_{a, t, g} \\
F_{a, t, g}=S_{a, g} \cdot E_{t, g} \cdot q_{a, t, g}
\end{gathered}
$$

The number of individuals needs to be transformed into mass units to compute spawning stock biomass $(S S B)$ and catches $(C)$. This is obtained through von Bertalanffy's growth equation (Eq. 6), which relates age $(a)$ of the individuals to an estimated length $\left(l_{a}\right)$ through an asymptotic length parameter $\left(L_{\infty}\right)$, a particular age at length $0\left(t_{0}\right)$ and a growth rate $(k)$, and the length-weight relationship (Eq. 7), which relates the length $\left(l_{a}\right)$ of a targeted individual of age $a$ to its weight $\left(w_{a}\right)$ through two parameters $(\alpha, \beta)$ :

$$
\begin{gathered}
l_{a}=L_{\infty}\left(1-\exp \left(-k\left(a-t_{0}\right)\right)\right) \\
w_{a}=\alpha \cdot\left(l_{a}\right)^{\beta}
\end{gathered}
$$

With the mean weights by age, the mean biomass by age is calculated (Eq. 8):

$$
\bar{B}_{a}=\bar{N}_{a} \cdot w_{a}
$$

The total mean biomass of a population of a species with a maximum age $m$ is:

$$
\bar{B}=\sum_{a=1}^{m} \bar{B}_{a}
$$

The catches of age $a$ in mass units can also be calculated for a fishing gear $g$ and time t:

$$
C_{a, t, g}=F_{a, t, g} \bar{B}_{a, t}
$$


The total catch by age, gear and both are, respectively:

$$
\begin{gathered}
C_{a, t}=\sum_{g=1}^{G} C_{a, t, g} ; C_{t, g}=\sum_{a=1}^{m} C_{a, t, g} \\
C_{t}=\sum_{a=1}^{m} \sum_{g=1}^{G} C_{a, t, g} \\
S S B_{t}=\sum_{a=1}^{m} S S B_{a, t}=\sum_{a=1}^{m} I_{a} \cdot \bar{B}_{a, t}
\end{gathered}
$$

To carry out the simulations, a model of the number of fish incorporated in the population, recruitment, at each time $t$ is required $\left(N_{0, t}\right)$. The models employed typically relate spawning stock biomass to recruitment, but due to the absence of information on stock/recruitment relationships for the species studies, the simulations were run with constant recruitment $\left(N_{0}=R\right)$.

At vessel level, the dynamics of catchability (related to age $a$, vessel $v$ and time $t$ ) are given by Equation 15 . The initial catchability of a vessel $\mathrm{v}$ in year 0 is $Q_{a, 0, v}$. The parameter $\tau$ is the annual increase in catchability. The annual increase in catchability coefficient simulates the constant increase in technology.

$$
q_{a, t, v}=Q_{0, a, v} \cdot(1+\tau)^{t}
$$

In addition to describing the population dynamics of a finite number of target species, the model also includes a description of a pool of secondary species fished jointly with the target species. The model does not incorporate ecological or other inter-species interactions (such as predation or competition). The secondary species landings $(Y)$ dynamics are expressed as a function of the landings of target species $(C)$ through an empirical relationship (Eq. 16):

$$
Y=\mu+v \cdot C
$$

where $\mu$ and $v$ are parameters estimated by linear regression from data on landings for target and secondary species.

\section{The market box}

The market sub-model describes the price formation process, transforming the landings of each individual vessel into revenues. The revenues of a vessel $\left(T R_{v}\right)$ are the income derived from the sale of the tar- get species at price $p$ and secondary species at price $p s$.

$$
T R_{v}=p \cdot C+Y \cdot p s
$$

The price of the target and the secondary species are taken as constant over time.

\section{The fisherman box}

In the model, the individual vessel, as an economic agent, assumes that production depends on the effort and catchability applied. The costs of the time period $t$ are deducted from the revenues, producing the net results or profits. Depending on the sign (negative or positive) and the magnitude of the profits, the individual vessel may change its effort or catchability in the next time period, constrained by the maximum legal limit of number of days at sea or the possibility of investing in technology, as imposed by legislation.

The balance between revenues and costs will thus determine fishermen's decision. The expenses that the fishermen must meet are divided into 7 groups (Table 1):

C1 Trade costs. The model considers trade costs to be those that can be expressed as a percentage of the total revenues $\left(T R_{v}\right)$ obtained by a vessel $(v)$. They include fishermen's association taxes, commercialisation taxes, local taxes, the sales process, etc. They are expressed as a percentage of the total revenues $\left(c l_{f}\right)$. The percentage of revenues $\left(c l_{f}\right)$ paid is the same for all the vessels in a fleet, hence this percentage is introduced at fleet level.

$$
C 1_{v}=c 1_{f} T R_{v}
$$

C2 Daily costs. These are the costs derived from the fishing activity. They are related to the vessels' costs of a unit of effort $\left(c 2_{v}\right)$. As the unit of effort is the number of days at sea, these costs represent the cost of a particular vessel operating for one day. They include fuel costs, net mending, daily food expenses and any other daily costs.

$$
C 2_{v}=c 2_{v} E_{v}
$$

C3 Labour costs. These are composed of the share corresponding to the owner after deducting the common costs $C 1$ and $C 2$. The percentage or share $\left(c 3_{f}\right)$ is the same for all vessels in a fleet, hence this percentage is introduced at fleet level. 


$$
C 3_{v}=c 3_{f} \cdot\left(T R_{v}-C 1_{v}-C 2_{v}\right)
$$

C4 Compulsory costs. Yearly costs incurred by the fisherman for keeping his business legal. The model assumes them to be constant and related to the vessel.

C5 Maintenance costs. The costs required to maintain the vessel at its maximum performance level. They are included in the reinstatement of the used capital, repairs, etc.

C6 Opportunity costs. The cost of using the capital invested $\left(\operatorname{In} v_{v}\right)$ and the rate of the country's public debt $\left(c \sigma_{c}\right)$. This determines what the capital's alternative profitability would be if it were invested elsewhere in a fixed time. It indicates the revenues lost to the fisherman by investing in the fishing activity.

$$
C 6_{v}=c 6_{c} \operatorname{In} v_{v}
$$

C7 Financial costs. Interest and capital return on bank loans. In case of negative profits, debts arise and any further investment requires bank loans. $C 7$ depends on banking interest rates $(c 7)$ and the individual debt $\left(D_{v}\right)$ incurred. The interest rate is given at country level.

$$
C 7_{v}=c 7_{c} D_{v}
$$

$D_{v}$ has an upper limit (maximum debt accepted by the banks) depending on the total capital invested. It simulates that the bank will not be interested in lending more than the maximal percentage authorised by the bank multiplied by the capital of the vessel.

Regarding the fishermen's financial health after one unit of time, there exist four possible results. The simulation model describes fishermen's priorities in response to these results.

\section{1) Positive profits}

The profits in the model are totally reinvested in increasing effort up to the legal maximum effort.

\section{2) Negative profits}

The fisherman will tend to maintain the same level of effort by borrowing money through bank loans. The loans each year are accumulated until the bank's maximum loan is reached. In the model, this limit is determined by the capital of the ship and the maximum capital percentage determined by each bank. For simulation purposes it is introduced as a country level parameter. If credit is obtained, the result is that catchability and effort are maintained, but the next year a new added cost (financial cost, $C 7)$ will exist in the vessel's cost structure. When the credit limit is exceeded, the possibility of obtaining new loans disappears and we examine the third possibility below.

\section{3) Negative profits and no loan, but unavoidable costs can still be met}

If the fisherman cannot cover the costs and can no longer borrow money to maintain catchability and effort, other costs must be reduced. The fisherman will reduce all the avoidable costs in the short term, starting with the avoidable part of maintenance costs $\left(C 5^{l}\right)$. This will produce a capital reduction but effort will be maintained. The fisherman will try to fish the maximum days allowed but if the losses are greater than the avoidable maintenance costs, he will be forced to reduce other costs. The only option is to reduce variable costs $(C 2)$. As a consequence, the fuel consumption will be reduced by reducing fishing effort so as to limit the variable daily expenses incurred.

\section{4) Negative profits, no loan, and unavoidable costs cannot be met}

If losses become greater than the avoidable costs, the fisherman can no longer meet these unavoidable expenses and he ceases fishing. In this case, the individual effort disappears from the fishery. The decrease of fishing mortality will be to the benefit of

\begin{tabular}{|c|c|c|c|c|}
\hline \multirow[t]{2}{*}{ Short-term costs } & Variable costs & $\begin{array}{l}\text { Trade costs } \\
\text { Daily costs } \\
\text { Labour costs }\end{array}$ & $\begin{array}{l}\mathrm{C} 1 \\
\mathrm{C} 2 \\
\mathrm{C} 3\end{array}$ & $\begin{array}{l}\text { Function of catch } \\
\text { Function of effort } \\
\text { Function of effort }\end{array}$ \\
\hline & Fixed costs & $\begin{array}{l}\text { Compulsory costs } \\
\text { Maintenance costs }\end{array}$ & $\begin{array}{l}\mathrm{C} 4 \\
\mathrm{C} 5\end{array}$ & $\begin{array}{c}\text { Constant } \\
\text { Function of profits }^{(1)}, \text { constant }^{(2)}\end{array}$ \\
\hline Long-term costs & & $\begin{array}{l}\text { Opportunity costs } \\
\text { Financial costs }\end{array}$ & $\begin{array}{l}\text { C6 } \\
\text { C7 }\end{array}$ & $\begin{array}{l}\text { Function of price of money } \\
\text { Function of interest rates }\end{array}$ \\
\hline
\end{tabular}
the remaining vessels.

TABLE 1. - Cost analysis by vessel.

\footnotetext{
${ }^{1}$ Costs are devoted to improvement of the vessel (capital increase) and are avoidable.

${ }^{2}$ Represent the minimum unavoidable maintenance costs of the vessel.
} 
TABLE 2. - Species growth parameters.

\begin{tabular}{|c|c|c|c|}
\hline \multicolumn{2}{|c|}{ Hake (Merluccius merluccius) } & \multicolumn{2}{|c|}{ Red mullet (Mullus barbatus) } \\
\hline Length-weight relationship & Von Bertalanffy growth equation & Length-weight relationship & Von Bertalanffy growth equation \\
\hline $\begin{array}{c}\alpha=0.006 \\
\beta=3.13\end{array}$ & $\begin{array}{c}\mathrm{L} \inf (\mathrm{cm})=73.12 \\
\mathrm{k}\left(\text { years }^{-1}\right)=0.2725 \\
\mathrm{t}_{0}(\text { years }=-0.15\end{array}$ & $\begin{array}{c}\alpha=0.007 \\
\beta=3.24\end{array}$ & $\begin{array}{c}\mathrm{L} \inf (\mathrm{cm})=24.58 \\
\mathrm{k}\left(\text { years }^{-1}\right)=0.29 \\
\mathrm{t}_{0}(\text { years })=-1.08\end{array}$ \\
\hline
\end{tabular}

TABLE 3. - Species cohort initial conditions.

\begin{tabular}{|c|c|c|c|c|c|c|c|c|c|}
\hline \multirow[b]{2}{*}{ Age } & \multicolumn{4}{|c|}{ Hake (Merluccius merluccius) } & \multicolumn{5}{|c|}{ Red mullet (Mullus barbatus) } \\
\hline & No ind. & $\mathrm{F}$ (trawl) & M & Maturity & No ind. & $\mathrm{F}($ trawl) & $\mathrm{F}$ (seine) & M & Maturity \\
\hline 0 & $8673166(\mathrm{R})$ & 0.82 & 0.43 & 0.019 & $6038294(\mathrm{R})$ & 0.052 & 0.016 & 0.46 & 0.169 \\
\hline 1 & 2485852 & 2.272 & 0.43 & 0.167 & 3564545 & 0.439 & 0.115 & 0.46 & 0.717 \\
\hline 2 & 166664 & 1.778 & 0.43 & 0.511 & 1293030 & 0.778 & 0.115 & 0.46 & 0.894 \\
\hline 3 & 18321 & 1.141 & 0.43 & 0.905 & 334134 & 0.853 & 0.07 & 0.46 & 0.975 \\
\hline 4 & 3806 & 0.652 & 0.43 & 1 & 83847 & 1.167 & 0.073 & 0.46 & 0.997 \\
\hline 5 & 1290 & 0.290 & 0.43 & 1 & 15309 & 0.843 & 0.024 & 0.46 & 1 \\
\hline 6 & 628 & 0.500 & 0.43 & 1 & 4061 & 1.18 & 0.000 & 0.46 & 1 \\
\hline 7 & - & - & - & - & 788 & 0.5 & 0.000 & 0.46 & 1 \\
\hline
\end{tabular}

\section{Simulation}

The objective of the simulation model is to carry out projections starting from the current situation forwards into the future with the purpose of analysing the behaviour of the fishery under different management actions. The simulation model is projected 15 years under stochastic conditions (1000 simulation runs), assuming uncertainty in the recruitment process (lognormal distribution function with mean $=R$ in Table 3 and sd $=0.1$ ). The results of the simulations are probability distributions of the selected indicators (biomass, spawning stock biomass $(S S B)$, profits by fleet and fishing mortality), represented by the mean, 5 and $95 \%$ confidence levels.

\section{Data source}

Field sampling was performed in 1999 to collect data for biological (Diapouli et al., 2000; Kalagia et al., 2000; Kalagia and Karlou-Riga, 2003) and economic parameter estimation (Karlou-Riga, unpublished data). The parameters used for simulation purposes are related to the description of the exploited populations (Tables 2 and 3), vessel and fleet economic and market characteristics (Tables 4 and 5).

\section{Management scenarios}

The management actions are tested as scenarios
TABLE 4. - Average vessel and fleet characteristics.

\begin{tabular}{lcc}
\hline & Trawlers & Beach seiners \\
\hline Number of vessels & 18 & 35 \\
Capital (euros/vessel) & 532753 & 44560 \\
Gross tonnage (gt/vessel) & 92 & 7.3 \\
Crew (persons/vessel) & 6.5 & 4 \\
Trade costs c1 (\%) & 9.8 & 9.8 \\
Annual cost & & \\
(C2+ C4 + C5 euros/year/vessel) & 140419.1 & 5353.1 \\
Labour cost (c3,\% for the owner) & 100 & 100 \\
Opportunity cost (c6, \% inv) & 2.5 & 2.5 \\
Interest rate c7 (\% debt) & 6.2 & 6.2 \\
Maximum debt accepted (\% capital) & 75 & 75 \\
Fishing days (days/year) & 226 & 110 \\
Annual increase in q (\%) & 1 & 1 \\
&
\end{tabular}

${ }^{1}$ The fishery analysed is an exception in the Mediterranean 'share system'. The crew of the fleets receive a salary.

in the MEFISTO bioeconomic model. Some are realistic, such as the increase in mesh size of trawlers from 28 to $40 \mathrm{~mm}$ that took place in 2000 and the withdrawal of eleven of the 35 beach seiners that took place in 2002, while other scenarios are policy proposals, such as the total withdrawal of the beach seine fleet and an effort reduction of $12 \%$ in trawler activity.

Scenario 1. In $2000(\mathrm{t}=1)$, trawl mesh size was changed to $40 \mathrm{~mm}$ stretched mesh. The resulting changes in the selectivity parameters and their consequences in the biological and economic indicators are analysed. Moreover, the effort reduction in beach seiners arising from the withdrawal of eleven vessels in $2002(\mathrm{t}=3)$ is simulated.

Scenario 2. The effect of the proposed policy measure of complete withdrawal of beach seiners is 
TABLE 5. - Market parameters.

\begin{tabular}{|c|c|c|}
\hline & $\begin{array}{c}\text { Hake } \\
\text { (M. merluccius) }\end{array}$ & $\begin{array}{l}\text { Red mullet } \\
\text { (M. barbatus) }\end{array}$ \\
\hline \multicolumn{3}{|l|}{ Trawlers } \\
\hline Price (euros/kg) & 5.54 & 5.58 \\
\hline$v(\mathrm{~kg}$ secondary $/ \mathrm{kg}$ target $)$ & 20 & 0 \\
\hline$\mu$ (kg secondary) & 1 & 0 \\
\hline ps (euros $/ \mathrm{kg}$ ) & 10.4 & 0 \\
\hline \multicolumn{3}{|l|}{ Beach seiners } \\
\hline Price (euros/kg) & - & 5.7 \\
\hline$v(\mathrm{~kg}$ secondary $/ \mathrm{kg}$ target $)$ & - & 10 \\
\hline$\mu$ (kg secondary) & - & 1 \\
\hline ps (euros/kg) & - & 9.7 \\
\hline
\end{tabular}

analysed through this scenario, placed as a management event in the fifth year of simulation $(t=5)$ and it is added to Scenario 1.
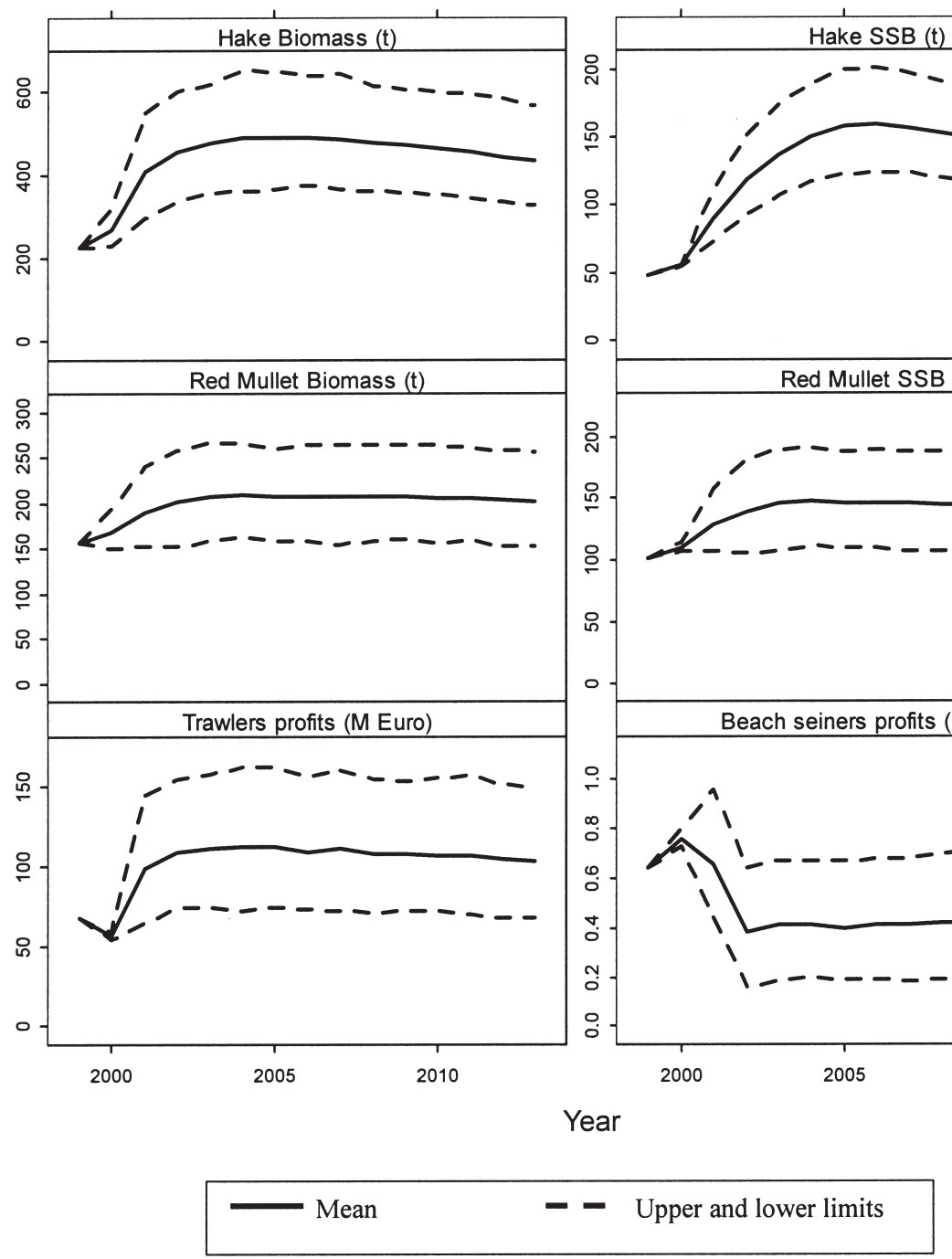

FIG. 1. - Evolution of bioeconomic indicators in a 15-year stochastic simulation. Note that the mesh size change in 2000 and the beach seiner effort reduction in 2002 have some effects on the displayed variables. The projections show the average trajectory and their 5 and $95 \%$

confidence intervals.
enter

Scenario 3. The effect of a proposed effort reduction in trawler activity is tested. The legal period of fishing is reduced by $12 \%$ in year $t=5$ of the simulation. The effects are analysed and added to Scenario 1.

\section{RESULTS}

\section{Scenario 1}

A fifteen-year projection from 1999 to 2013 is shown in Figure 1 with the management actions that took place in 2000 and 2002. This figure reflects the real trends of the bioeconomic indicators of the Saronikos Gulf hake and red mullet fisheries after the change of the trawlers' mesh size and the with-

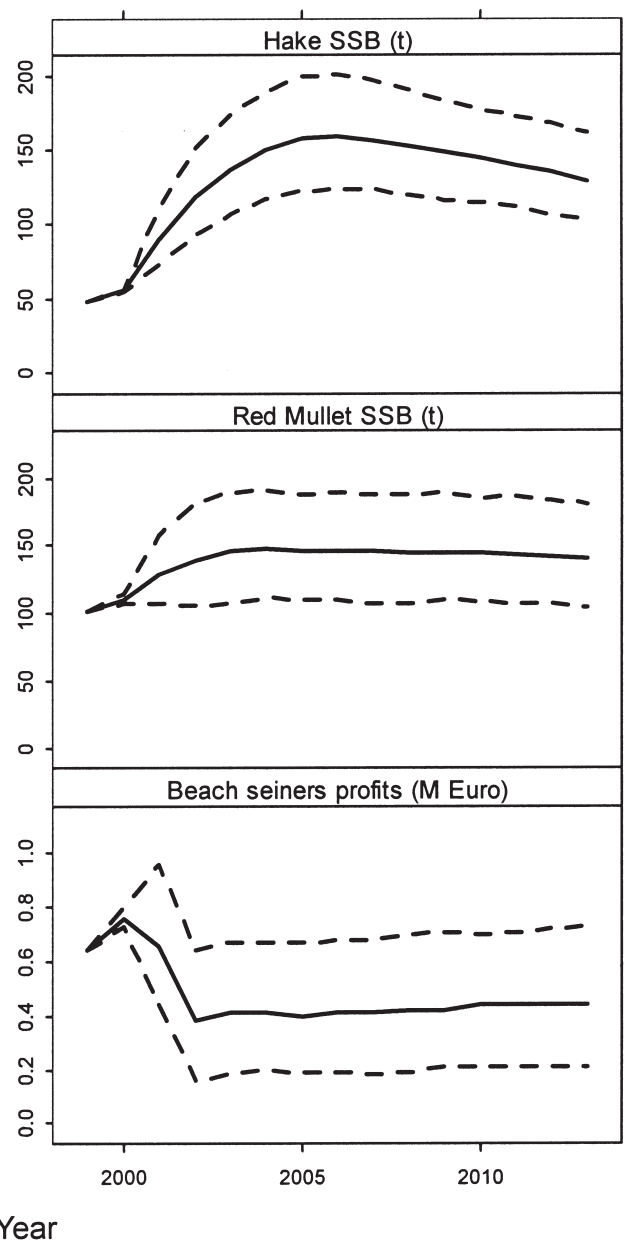




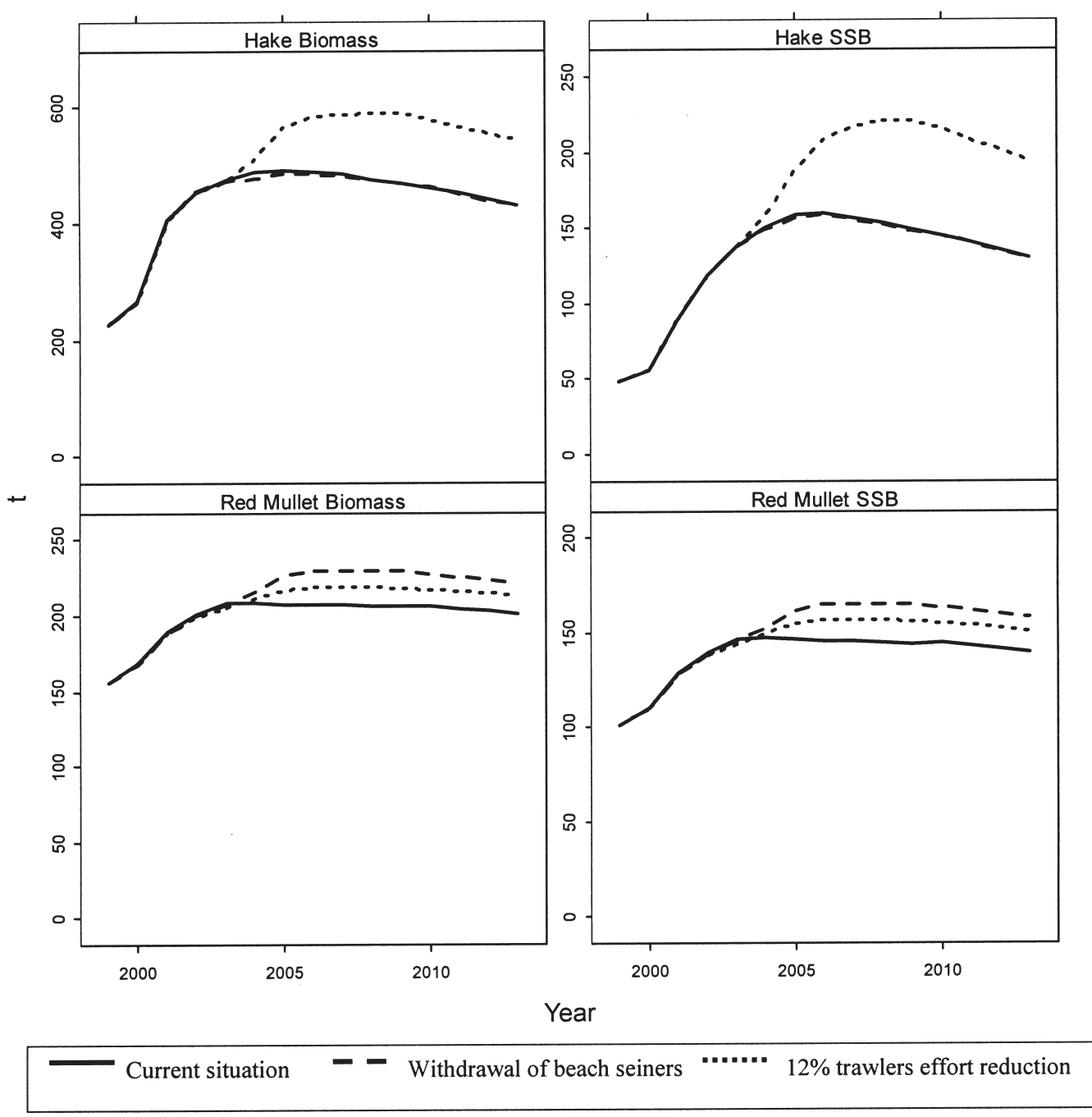

FIG. 2. - Species average biomass and expected evolution of spawning stock with the two management actions proposed as Scenarios 2 and 3 located in 2004 .

drawal of eleven beach seiners. The upper and lower limits of the displayed variables represent the uncertainty of the bioeconomic predictions due to the stochasticity in the recruitment process.

The change in mesh size that took place in 2000 has proved to be very useful for the recovery of both species whose juveniles have been reported to be overexploited in the Saronikos Gulf, and also in many Mediterranean fisheries (Karlou-Riga et al., 2000; Karlou-Riga and Vrantzas, 2001; Karlou-Riga et al., 2005; Fernandez et al., 2006; GarcíaRodriguez et al., 2006; Guijarro et al., 2006; Jadaud et al., 2006). The profitability of the trawl fleet should have been improved after the change in mesh size that brought economic losses only in the first year of its implementation. In the medium term, the profits for the trawlers operating in the Saronikos Gulf would double after the mesh size change and would be very slightly improved after the effort reduction of beach seiners (2002) that contributed very slightly to the recovery of red mullet. The effort reduction of beach seiners did not bring positive effects to trawlers, which initially suggests that it is not causing the overexploitation of red mullet. If this were the case, an effort reduction of beach seiners would bring positive effects in the medium term. As is observed, in the medium term there is a very slight increase in profits but they are far from the profits before the beach seiner effort reduction in 2002 and even the trawlers' mesh change in 2000.

\section{Scenarios 2 and 3}

Figures 2 and 3 show the effects of two potential management actions. The time of both management actions is 2004 and its effects on the bioeconomic 


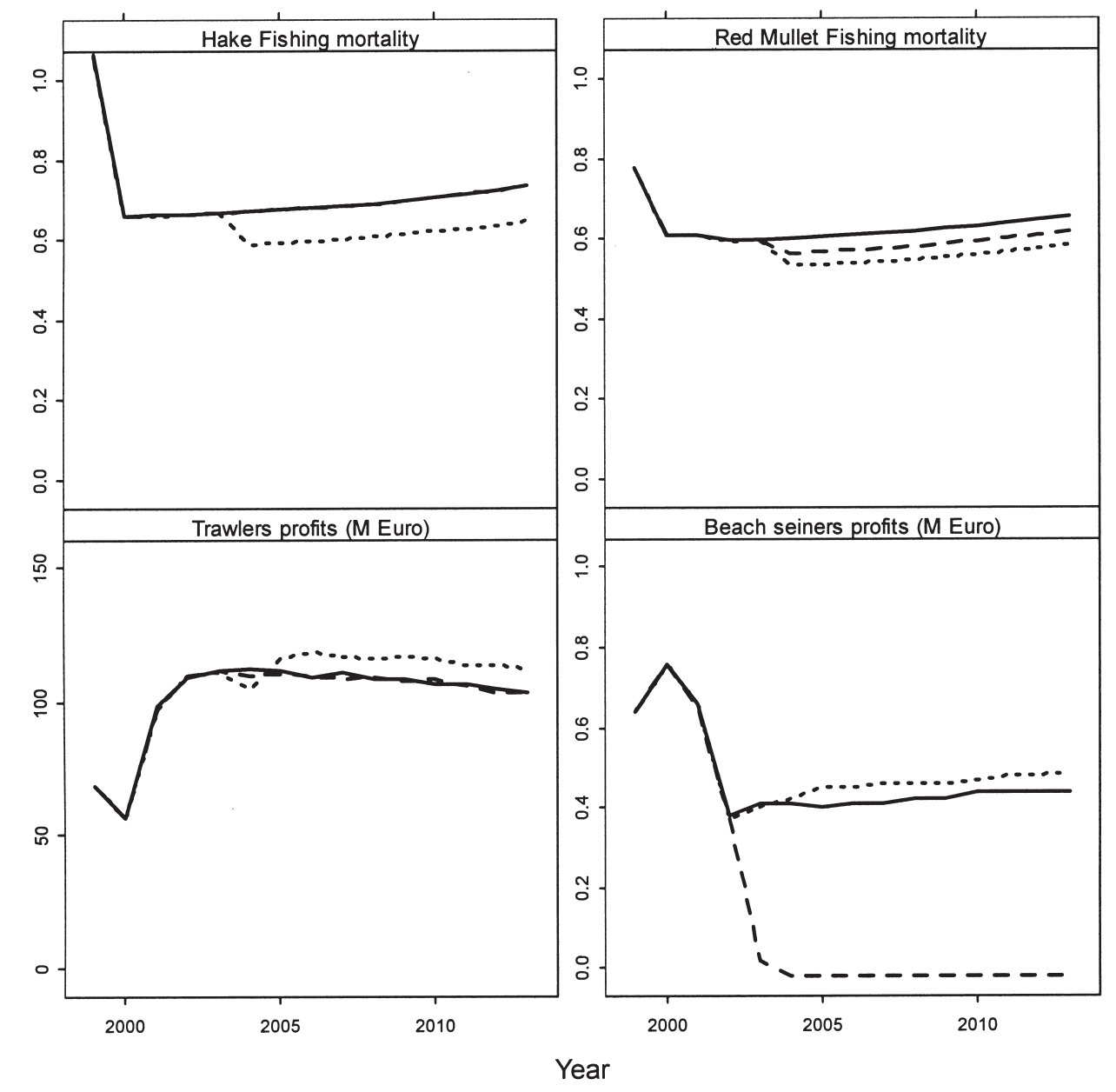

Current situation $\quad-\quad-$ Withdrawal of beach seiners $\cdots \cdots \cdots 12 \%$ trawlers effort reduction

FIG. 3. - Species average fishing mortality projections and fleet profits expectation with the two management actions proposed as Scenarios 2 and 3 located in 2004.

indicators of Saronikos Gulf's hake and red mullet exploitation are predicted. The hake population would respond to the $12 \%$ effort reduction of trawlers activity with a significant increase. Red mullet increases its population level after both the effort reduction of trawlers and the total withdrawal of the beach seiners. The positive effect on the population is higher with the withdrawal of beach seiners (Fig. 2).

The fishing mortalities applied to both populations would be significantly reduced after the management actions explained in Scenario 1 and they would be further reduced with the reduction in trawler effort and the complete withdrawal of beach seiners. The most significant effect is obtained with the trawlers' $12 \%$ effort reduction. The profitability of trawlers, which should have improved with the management actions taken in 2000 and 2002, would be further improved after subsequent effort reduction. The improvement would be observed two years after its implementation. On the other hand, beach seiners would benefit from this effort reduction but the profitability of the activity would remain far from its levels in 1999 when there were 35 vessels. The complete withdrawal of beach seiners would not bring significant positive effects on trawlers (Fig. 3).

\section{DISCUSSION}

The recent assessments by the SCSA in the GFCM indicate an $11 \%$ increase in hake catches after the implementation of the change in mesh size that took place in 1999-2000 (Karlou-Riga et al., 2005). The increase in hake biomass and trawlers' 
profits in the short run of the simulation shown in Figure 1 is concordant with this report, which highlights the need to incorporate data from other gears. The multi-species and multi-gear simulation exercise presented here aims to describe the interactions between trawler and beach seine fleets sharing the exploitation of red mullet. The red mullet population is simulated (with MEFISTO) to recover by around $25 \%$ with the current management actions of mesh size change for trawlers and the withdrawal of eleven vessels in 2002.

The recommendations for the hake fishery management in the Saronikos Gulf mention a necessary effort reduction of $68 \%$ to achieve the maximum sustainable yield (Karlou-Riga et al., 2005). The presented simulation of a $12 \%$ effort reduction for the trawlers' activity, which represents the prohibition of fishing for one month in the current fishing period of 8 months, shows a significant positive effect, especially on the hake population. The effort reduction is added to the current selectivity pattern after the change in trawlers' mesh size in 2000 and contributes positively to the recovery of the hake population. The trawling fleet benefited by their effort reduction but this benefit is unrelated to the positive effect after the change in mesh size. The positive effects of the change of selectivity patterns have also been proved in multi-species bottom trawl fisheries in the Mediterranean (Sardá et al., 2006). The effort reduction in trawlers' activity in year 5 brings a slight recovery of red mullet and a low increase in profits for the beach seiner fleet.

According to the fishing mortality pattern of the two fleets (Table 3) it is clear that beach seiners catch mainly red mullet of cohorts 1 and 2 and trawlers fish individuals of cohorts 3 to 6 . This difference is assumed to have increased after the change in trawlers mesh size in year 1 of the simulation. Although the trawlers' effort reduction results in a higher average fishing mortality reduction of red mullet, the biomass increase after the beach seiners' withdrawal is more positive. The latter occurs because the withdrawal of the beach seiners leads to a higher reduction in fishing mortality of juveniles, leading to an increase in the red mullet population. The harm that beach seiners cause to red mullet juveniles is one of the complaints of the longline and net fleets, as was stated in the introduction.

Another salient aspect of the simulation exercise is the almost null effect of the complete withdrawal of the beach seiner fleet for the economic profitability of trawlers.

Comparing the present analysis with the MEFISTO simulation analysis in the Gulf of Lions (Lleonart et al., 2003), where two trawler and longliner fleets exploit hake, some similarities can be found. First, the $29.6 \%$ effort reduction in the trawlers' activity brings a significant recovery in the hake populations, increasing their abundance by $500 \%$ in the 25 years of simulation. On the other hand, the recovery seems to be slower in the Gulf of Lions case. The two analyses indicate the need to protect hake juveniles with an effort reduction of the trawling activity, while the Gulf of Saronikos case supports the change in mesh size that took place in 1999-2000. Lleonart et al., (2003) report the positive impact of measures aimed at protecting juveniles through selectivity measures but suggest the need for effort reductions in the trawling fleet.

To sum up, it can be concluded that a correct management of the Saronikos Gulf fisheries would be reached through selectivity and effort control of the trawling fleet. The positive effect of the trawlers' mesh size change is reported, and it is suggested that higher effort reductions would allow management goals to be achieved (Karlou-Riga et al., 2005). The withdrawal of the beach seiners would lead to a significant recovery in the red mullet population by preserving their juveniles, but it would not have observable effects on the profitability of the trawling fleet. The fleet interactions are only significant in one direction: the activity of trawlers greatly affects the profits of the beach seiner fleets, but this does not happen in the opposite direction.

\section{ACKNOWLEDGEMENTS}

We thank Triantafyllos Kountouris and Argyris Argyrokastritis for their help and advice in the in situ approach to the hake and red mullet fishery in the Gulf of Saronikos and all the staff in the Fisheries Laboratory of the Ministry of Rural Development and Food.

\section{REFERENCES}

Diapouli, E., N. Vrantzas, M. Kalagia and C. Karlou. - 2000. Age and growth of hake (Merluccius merluccius) in the Saronikos gulf (in Greek with English abstract), Proc. 9 ${ }^{\text {th }}$ Panhellenic Conf. Ichthyologists, Messologi (Greece). 33-36. 
Griffin, W L _ - 2003 A General Bioeconomic Fisheries Simulation Model: Description, Calibration, Validation, and Application, Proc. $1^{\text {st }}$ North Am. Fish. Econ. Forum. 97-112.

Horwood, J.W. - 1994. Modelling of fisheries management strategies. Privately published, Ministry of Agriculture, Fisheries and Food, Lowestoft (U.K.).

Kalagia, M. and C. Karlou-Riga. - 2003. Comparative study of red mullet growth between different areas and different periods, Proc. 11 $1^{\text {th }}$ Panhellenic Conf. Ichthyologists, Preveza (Greece). 87-90.

Kalagia, M., N. Vrantzas and C. Karlou. - 2000. Age and growth of red mullet (Mullus barbatus) in the Saronikos gulf (in Greek with English abstract), Proc. $9^{\text {th }}$ Panhellenic Conf. Ichthyologists, Messologi (Greece). 37-40.

Karlou-Riga, C., I. Anastopoulou and A. Argyrokastritis. - 2005. Hake (Merluccius merluccius) Stock Assessment in the Saronikos Gulf (GFCM Geographical Sub-Area 22) in 2004

Karlou-Riga, C. and N. Vrantzas. - 2001. Assessment of the state of some demersal fish stocks in the Saronikos Gulf and the Cyclades islands. WD, $2^{\text {nd }}$ Session of the Working Group on Demersal Fisheries, GFCM-SAC, Tunis, Tunisia, 13-16 March 2001

Karlou-Riga, C., N. Vrantzas and M. Kalagia. - 2000. Evaluation of state of stocks for red mullet (Mullus barbatus) and hake (Merluccius merluccius) in the Saronikos Gulf (Greece). WD, $1^{\text {st }}$ Session of the Working Group on Demersal Fisheries, GFCM-SAC, Sète, France, 21-23 March 2000.

Lleonart, J. and F. Maynou. - 2003. Fish stock assessments in the Mediterranean: state of the art. Sci. Mar., 67: 37-49.

Lleonart, J., F. Maynou, L. Recasens and R. Franquesa. - 2003. A bioeconomic model for Mediterranean fisheries, the hake off Catalonia (western Mediterranean) as a case study. Sci. Mar., 67: $337-351$
Maynou, F., F. Sardá, S. Tudela and M. Demestre. - 2006. Management strategies for red shrimp (Arsiteus antennatus) fisheries in the Catalan sea (NW Mediterranean) based on bioeconomic simulation models. Aquat. Liv. Res., 19: 161-171.

NSSG. -2000 . Results of the sea fishery survey by motor vessels (for the years 2003). 46

Punt, A.E. - 1992. Selecting management methodologies for marine resources with an illustration for Southern African hake. S. Afr. J.Mar. Sci., 12: 943-958.

Punt, A.E. - 1993. The comparative performance of production model and adhoc tuned VPA based feed back control management procedures for the stock of Cape hake off the West Coast of South Africa. Can. Spec. Publ. Fish. Aq. Sci., 120.

Sardá, F., N. Bahamón, B. Molí and F. Sardá-Palomera. - 2006. The use of a square mesh codend and sorting grids to reduce catches of young fish and improve sustainability in a multispecies bottom trawl fishery in the Mediterranean. Sci. Mar., 70(3): 347-353.

Schnute, J. - 1985. A general theory for analysis of catch and effort data. Can. J. Fish. Aq. Sci., 42: 414-429.

Sparre, P.J. and R. Willman. - 1993. Software for bio-economic analysis of fisheries. BEAM 4. Analytical Bio-economic Simulation of Space-structured Multispecies and Multi-fleet Fisheries. Vol. 1. Description of the model. Computerized information series (Fisheries). FAO, 186.

Ulrich, C., B. Le Gallic, M.R. Dunn and D. Gascuel. - 2002. A multi-species, multi-fleet bioeconomic simulation model for the English Channel artisanal fisheries. Fish. Res., 58: 379-401.

Scient. ed.: A. Guerra.

Received March 2, 2007. Accepted May 2, 2007.

Published online July 11, 2007. 